\title{
Substance Use Reason Not Collected
}

National Cancer Institute

\section{Source}

National Cancer Institute. Substance Use Reason Not Collected. NCI Thesaurus. Code C83425.

The rationale why substance use data was not obtained. 